\title{
Genotype and sex effects on carcass and meat quality of suckling kids protected by the PGI "Cabrito de Barroso"
}

\author{
V.A.C. Santos ${ }^{\text {a, }}$, A.O. Silva ${ }^{\text {a }}$, J.V.F. Cardoso ${ }^{\text {b }}$, A.J.D. Silvestre ${ }^{\text {c }}$, S.R. Silva ${ }^{\text {a }}$, \\ C. Martins ${ }^{\text {a }}$, J.M.T. Azevedo ${ }^{\text {a }}$ \\ ${ }^{a}$ CECAV - University of Trás-os-Montes and Alto Douro, Animal Science Department, Apartado 1013, 5001-801 Vila Real, Portugal \\ ${ }^{\mathrm{b}}$ CETAV - University of Trás-os-Montes and Alto Douro, DEBA, 5001-801 Vila Real, Portugal \\ ${ }^{\mathrm{c}}$ University of Aveiro, Department of Chemistry, 3810-193 Aveiro, Portugal
}

Received 16 January 2006; received in revised form 8 September 2006; accepted 6 October 2006

\begin{abstract}
Carcass composition and meat quality traits were evaluated in 55 suckling kids (27 males and 28 females) from Serrana (S), Bravia (B) and Serrana $\times$ Bravia $(\mathrm{S} \times \mathrm{B})$ crossbred genotypes. Kids were slaughtered at $8-11 \mathrm{~kg}$ of live weight according to "Cabrito de BarrosoPGI" specifications and carcasses' left sides were totally dissected. Dressing percentage (based on ELW) did not vary between genotypes and sexes. Genotype B carcasses have better conformation, expressed in higher compactness index and muscle/bone ratio. Sex had no effect on the composition of dissected carcass but females deposited more internal fat than males. S genotype had significantly less muscle content and higher dissectible fat compared to B and $\mathrm{S} \times \mathrm{B}$ genotypes, suggesting differences in maturity stages. The carcass' bone content (20.4-21.4\%) did not differ significantly between genotypes. The longissimus thoracis et lumborum (LTL) and gluteobiceps (GB) muscles were used for meat quality determinations. Genotype had a significant effect on meat traits and fatty acid composition of the analysed muscles: B genotype and LTL muscle showed lower final $\mathrm{pH}, \mathrm{S} \times \mathrm{B}$ genotype had darker and more red muscles, GB muscle had a higher shear force value and lower collagen solubility. Few sex effects were observed on meat quality traits as well as on fatty acid composition. Average percentage of desirable fatty acids in kids was superior to $60 \%$ with male $\mathrm{S}$ genotype displaying a lower value. Genotypes B and $\mathrm{B} \times \mathrm{S}$, males and $\mathrm{GB}$ muscle had more favorable PUFA:SFA ratios.
\end{abstract}

(C) 2006 Elsevier Ltd. All rights reserved.

Keywords: Goat kids; European quality labels; Carcass; Meat quality; Fatty acids

\section{Introduction}

In Portugal and more specifically in the "Barroso" region (North of Portugal) there is a seasonal demand for meat from milk-consuming young goats, associated with the traditional consumption of light kids in festive seasons, such as Christmas, Easter and other popular festivities. This fresh suckling-kid meat is a really typical product regarded as having high edible quality. Since 1996 (Commission regulation EEC No. 1107/96) the European Union (EU) has granted this meat a Protected Geo-

\footnotetext{
* Corresponding author. Tel.: +351 259350430; fax: +351 259350482. E-mail address: vsantos@utad.pt (V.A.C. Santos).
}

graphical Indication (PGI), "Cabrito de Barroso". From the three European quality labels for suckling kid meat commercialized in Portugal the carcasses protected by this PGI represent $66.1 \%$ and obtain good market prices (INE, 2003). According to PGI specifications, carcasses of "Cabrito de Barroso" must weight from 4 to $6 \mathrm{~kg}$, be obtained from kids up to three months of age, raised on pasture with their mothers in the Barroso highlands, and belonging to the local Serrana (S) and Bravia (B) goat breeds or their crossbreeds $(\mathrm{S} \times \mathrm{B})$. Serrana is the most widespread national goat breed with a flock of 16,000 animals and Bravia flock has 9600 registered animals (SPOC, 2005).

As for other livestock, goat meat products have been evaluated according to carcass composition and meat quality. The meat quality concept is continuously changing and 
nowadays typical products, due to their history, originality and "natural image" are well accepted by consumers, who are more and more concerned about food origin (SantosSilva, Mendes, \& Bessa, 2002). Thus, it is important to have well characterized quality labels meats and provide such information to consumers. Goat meat composition and quality is influenced by genotype (Oman, Waldron, Griffin, \& Savell, 2000; Tshabalala, Strydom, Webb, \& Kock, 2003), sex (Hogg, Mercer, Mortimer, Kirton, \& Duganzich, 1992; Todaro et al., 2004), diet and production system (Johnson \& McGowan, 1998; Marinova, Banskalieva, Alexandrov, Tzvetkova, \& Stanchev, 2001), slaughter weight (Dhanda et al., 1999; Marichal et al., 2003) and age (Todaro et al., 2002). Nevertheless, other factors could influence meat quality such as pre-slaughter treatment, carcass chilling, muscle type or ageing time (Kadim et al., 2003).

Goats are known to produce relatively lean meat (Sen, Santra, \& Karim, 2004) and in the last few years there has been an increase in studies on lipid composition of goat meat as a meat quality indicator associated with other meat quality parameters (Webb, Casey, \& Simela, 2005). It is generally accepted that the fat composition of very young suckling animals is mainly related to the fat composition of the milk they consume (Velasco et al., 2000; Zygoyiannis, Kufidis, Katsaounis, \& Phillips, 1992). However, as soon as to the animals are given solid feed, the fat composition may be modified by the supplementary foodstuffs consumed (Doney, Smith, Sim, \& Zygoyiannis, 1984; Velasco et al., 2001).

European meat quality labels, such as "Cabrito de Barroso"-PGI have some specificity attributed to a particular region and to a traditional production method; however, only a few studies have been published on the determination of suckling kid carcasses and meat characteristics of either the Serrana or the Bravia breeds. The aim of the present study was to evaluate the effects of genotype and sex on carcass traits and meat quality parameters of kids protected by the PGI "Cabrito de Barroso".

\section{Materials and methods}

Animal handling followed the EU directive number 86/ 609/EEC concerning animal care.

\subsection{Animals and their management}

The present study was conducted with 55 suckling kids (28 males and 27 females) of three genotypes (18 B, $19 \mathrm{~S}$ and 18 crossbred $\mathrm{S} \times \mathrm{B}$ ) produced according to precise "Cabrito de Barroso-PGI" specifications. The selection of kids was done regardless of birth type. When very young, the kids were penned at the farm during the first two weeks, while their dams spent the day at pasture. After this period, kids were naturally suckled and left to graze with their dams.

\subsection{Slaughtering}

When kids individually reached $8-11 \mathrm{~kg}$ of live weight (21-27\% of mature live weight) they were taken from their dams to the experimental slaughterhouse of the "University of Trás-os-Montes and Alto Douro" in Vila Real. Live weights at slaughter were recorded after an overnight fast (Table 1) and kids were electrically stunned and slaughtered by exsanguination. The dressed carcass comprised the body after removing the skin, the head (at the occipital-atlantal joint), the fore feet (at the carpal-metacarpal joint), the hind feet (at the tarsal-metatarsal joint) and the viscera. Hot carcass weight $(\mathrm{HCW})$ and head weights, skin, some visceral organs (heart, liver, lungs, kidneys, pancreas, spleen, gastro-intestinal tract) were recorded. Weights of omental and mesenteric fat were obtained and digestive contents were removed to calculate empty live weight (ELW). Commercially, weights of "Cabrito de Barroso-PGI" carcasses include offal (head, liver, lungs, heart and kidneys) and have been assigned as carcass weight of the PGI (Table 1). Dressing percentage was calculated based on ELW.

\subsection{Carcass measurements, jointing and dissection}

Cold carcass weights $(\mathrm{CCW})$ were recorded after chilling at $4{ }^{\circ} \mathrm{C}$ for $24 \mathrm{~h}$ and the kidney knob and channel fat (KKCF) and kidneys were removed and their weights were recorded. Several carcass measurements outlined by Fisher and de Boer (1994) were taken from all carcasses: carcass length, pelvis width, hind limb length, chest width. Carcasses were split along the spine and chest depth and side

Table 1

Means ( \pm standard deviation) of slaughter live weight (SLW), empty live weight (ELW), hot carcass weight (HCW) and cold carcass weight (CCW) of male and female kids from Serrana $(\mathrm{S})$, Bravia $(\mathrm{B})$ and Serrana $\times$ Bravia $(\mathrm{S} \times \mathrm{B})$ crossbred genotypes

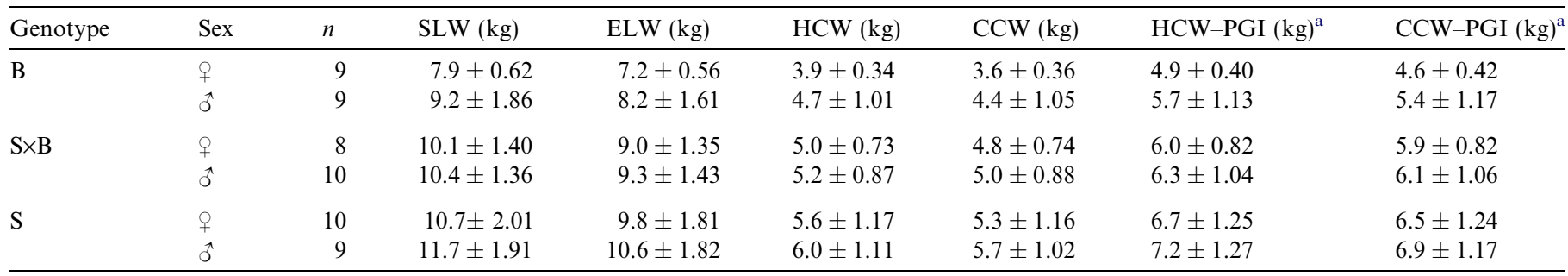

\footnotetext{
${ }^{a}$ PGI hot and cold carcass weight includes head, liver, lungs, heart and kidneys.
} 
length were recorded. Side length was registered from the cranial edge of the symphysis pelvis to the cranial edge of the first rib, in the centre of the visible part. Carcass compactness, used as a conformation indicator, was determined as the ratio between $\mathrm{HCW}$ and side length. The carcass left sides were separated in to eight standardized commercial joints as outlined by Santos-Silva et al. (2002) for lamb carcasses. After weighing, each joint was separated into dissectible muscle, bone, fat (subcutaneous and intermuscular fat depots were registered separately) and the remainder (major blood vessels, ligaments, tendons and thick connective tissue sheets associated with some muscles) in a dissection room under controlled environment.

\subsection{Muscle sampling}

Samples of longissimus thoracis et lumborum (LTL) and gluteobiceps (GB) muscles were taken $24 \mathrm{~h}$ after slaughter, from the loin and leg, respectively, when carcass left halves were partitioned into commercial joints. Sub-samples of LTL were taken for fatty acid profiles (1st to 3rd lumbar vertebra), colour and intramuscular fat (4th to final lumbar vertebra) analysis. Sub-samples of GB (medial portion) were taken for the same analyses. At the same time, carcass right LTL, between the 8 th rib and 5th lumbar vertebra and the GB (total) muscles were excised and divided into three parts. One part of the muscle was vacuum packed and aged at $2 \pm 2{ }^{\circ} \mathrm{C}$ for 5 days post-mortem for cooking losses and tenderness objective determinations. After epimysium removal, the remaining portions were cut and frozen at $-18^{\circ} \mathrm{C}$ until collagen and pigmentation determinations.

\subsection{Meat quality measurements}

The ultimate $\mathrm{pH}\left(\mathrm{pH}_{24}\right.$, measured at $24 \mathrm{~h}$ after slaughter) was measured directly in LTL (4/5th lumbar vertebra) and GB muscles (distal part) of the carcass' left side using a combined glass electrode with a pH-meter, Crison 2002. Muscle colour was evaluated immediately after cutting at the same site as $\mathrm{pH}_{24}$ using the $L^{*} a^{*} b^{*}$ system by a chromometer (Minolta 310), where $L^{*}$ depicts relative lightness, $a^{*}$ indicates relative redness and $b^{*}$ represents relative yellowness. Intramuscular fat was determined with $20.0 \mathrm{~g}$ (in duplicate) of minced meat in a Soxhlet apparatus using petroleum ether (NP-Norma Portuguesa-122, 1982). LTL muscle was used for sarcomere length determination, $24 \mathrm{~h}$ after slaughter, following the methodology described by Cross, West, and Dutson (1981). The length of 10 consecutive sarcomeres was measured (15 groups of 10 sarcomeres for each sample) under the phase microscope $(40 \times$ objective) with a video camera attached and using the image-analysing system Matrox Inspector. The pigment concentration in muscle samples was analyzed according to Boccard et al. (1981). Total collagen was determined, after acid hydrolysis, by spectrophotometric assay of L- hydroxyproline (AOAC, 1990). The amount of L-hydroxyproline in the supernatant and residue fractions was converted into soluble and insoluble collagen using 7.25 and 7.52 as factors (Cross, Carpenter, \& Smith, 1973). Collagen was expressed as total (soluble + insoluble) and soluble collagen as the percentage of the total. Cooking loss was determined in refrigerated meat samples of similar geometry, individually placed inside polyethylene bags in a water bath at $75^{\circ} \mathrm{C}$. Samples were heated until an internal temperature of $70{ }^{\circ} \mathrm{C}$ (monitored with thermocouples introduced in the core) and cooled for 15 min under running tap water. They were taken from the bags, dried with filter paper and weighed. Cooking loss was expressed as the percentage of loss related to the initial weight. After measurement of cooking loss, samples were stored in a refrigerator and used for objective tenderness determinations (after equilibration at room temperature). The Warner-Bratzler shear force (WBSF) was measured in sub-samples (at least three) of $1 \mathrm{~cm}^{2}$ cross-section and $3-4 \mathrm{~cm}$ in length with fibres perpendicular to the direction of the blade attached to a Stevens QTS 25 apparatus.

\subsection{Fatty acids analysis}

Lipid extraction from LTL and GB muscles was carried out according to procedures described by Marmer and Maxwell (1981) and transesterification with borontrifluoride in methanol according to Labadie, Laplaud, Rigaud, and Breton (1974). Fatty acid methyl esters (FAME) were analyzed using a Finnigan Trace Gas Chromatograph 2000 coupled with a Trace MS mass spectrometer, equipped with a DB-1 fused silica capillary column (J\&W Scientific, $30 \mathrm{~m} \times 0.32 \mathrm{~mm}$ i.d. $\times 0.32 \mu \mathrm{m}$ film thickness). The temperature program was $80{ }^{\circ} \mathrm{C}$ for $5 \mathrm{~min}$ then heated at the rate of $4{ }^{\circ} \mathrm{C} / \mathrm{min}$ to $285^{\circ} \mathrm{C}$, which was maintained for $10 \mathrm{~min}$. Injector and detector temperatures were both $290{ }^{\circ} \mathrm{C}$. The carrier gas was helium $(35 \mathrm{~cm} / \mathrm{s})$. Mass spectra were obtained in the EI mode $(70 \mathrm{eV})$. The identification of FAME was confirmed based on their characteristic fragmentation patterns and by comparing their mass spectra with spectral library equipments (Wiley-Nist). The chromatographic system was calibrated with pure reference compounds

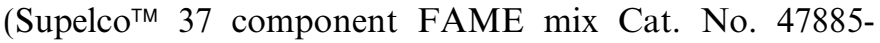
$\mathrm{U})$, using eicosane as an internal standard. The multiplication factors needed to obtain correct quantification from peak areas were calculated as an average of six GC-MS runs. As this column incompletely resolves isomers of $\mathrm{C} 18: 1$ and of $\mathrm{C} 18: 2$ acids each group of isomers is reported as a single value. Results are expressed as relative percentages.

To assess the nutritional implications of the various types of kid meat studied the desirable fatty acids (DFA), which are oleic acid and all unsaturated fatty acids (UFA), and UFA percentages, and the PUFA:SFA, UFA:SFA and (C18:0 + C18:1)/C16:0 ratios were determined (Banskalieva, Sahlu, \& Goetsch, 2000). 


\subsection{Statistical analysis}

Data were analysed using the GLM procedures of SAS (1999). Carcass traits and body composition were studied in order to evaluate the effects of genotype, sex and covariate and their interactions. The model included genotype and sex effects and the linear effect of ELW or HCW as covariate. The effect of interactions between main effects and covariate were included only when significant $(P<0.05)$. Meat quality parameters and fatty acid composition were studied in order to evaluate the effects of genotype, sex and muscle type and their interactions. Least-square means were computed and tested for differences by the Bonferroni test.

\section{Results and discussion}

Mean values obtained for slaughter live weight, empty live weight, hot and cold carcass weight of kids used in this study are presented in Table 1 . Hot and cold carcass weights of PGI are also presented.

\subsection{Carcass traits and composition}

Dressing percentages (based on ELW) did not differ between genotypes (Table 2). Similar results have previously been reported in other studies with different genotypes when dressing percentages are compared on an empty live weight basis which is not influenced by digestive content at slaughter (Johnson, McGowan, Nurse, \& Anous, 1995; Van Niekerk \& Casey, 1988; Warmington \& Kirton, 1990). Relatively to gender and in this weight range, dressing percentages were also not affected. The dressing percentage (based on ELW) of kids from three genotypes and two sexes ranged from 55.4\% to 56.5\% (Table 2). These values are within the range of reported values for Serrana kids (carcass weight: $6.9 \mathrm{~kg}$ ) by Teixeira, Azevedo, Delfa, Morand-Fehr, and Costa (1995) and Todaro et al. (2004) for Nebrodi kids (carcass weight: $5.3-5.7 \mathrm{~kg}$ ) and slightly superior of reported by Marichal, Castro, Capote, Zamorano, and Argüello (2003) at similar carcass kids weight $(4.9 \mathrm{~kg})$. Dressing percentage of PGI (based on ELW) is near $70 \%$ for all genotypes and sexes (Table 2) as a result of this specific category in European quality labels that includes offal weights. The digestive content contributed $9.4-10.8 \%$ of SLW (Table 2) and was not affected by genotype and sex. Previous results of Marichal et al. (2003) with kids from the Canary Caprine Group reported $5.2 \%$ and $7.5 \%$ of digestive content at 6 and $10 \mathrm{~kg}$ slaughter weight, respectively. These differences between studies can be attributed to the type of diet and the fasting period prior to slaughter. Genotype B had more chilling losses than $\mathrm{S} \times \mathrm{B}$ and was affected by ELW, and consequently these numerical differences are due to differences in carcass size. The percentage contributions of various body components reported in the present study were similar to those reported for different breeds at similar live weights (Mahgoub, Kadim, Al-Saqry, \& Al-Busaidi, 2005; Marichal et al., 2003). The $\mathrm{S}$ genotype has heavier skin $(P<0.05)$ that could be due to differences between genotypes in hair cover, because the Portuguese Serrana breed is the only rustic goat breed with long hair cover (García, 2002). Sex affected the kids' internal fat depots distribution (Table 2) with females having significantly $(P<0.05)$ higher $\mathrm{KKCF}$, omental and mesenteric fat proportions. Similar results were found by Kirton (1970) and Mahgoub and $\mathrm{Lu}(1998)$ for the same internal fat depots. In the present study, despite the kids' young age and that these fat

Table 2

Male and female kids' carcass traits and non-carcass components (least-square means \pm standard error) for Serrana (S), Bravia (B) and Serrana $\times$ Bravia $(\mathrm{S} \times \mathrm{B})$ crossbred genotypes

\begin{tabular}{|c|c|c|c|c|c|c|c|c|c|}
\hline \multirow[t]{2}{*}{ Traits } & \multicolumn{3}{|c|}{ Genotype (Gen) } & \multicolumn{2}{|l|}{ Sex } & \multicolumn{4}{|c|}{ Effects } \\
\hline & B & $\mathrm{S} \times \mathrm{B}$ & $\mathrm{S}$ & q & $\hat{0}$ & Gen & Sex & ELW & Gen $\times$ Sex \\
\hline Dressing percentage (ELW basis) & $56.5 \pm 0.53$ & $55.4 \pm 0.47$ & $56.3 \pm 0.50$ & $55.8 \pm 0.39$ & $56.3 \pm 0.38$ & NS & NS & * & NS \\
\hline Dressing percentage of PGI (ELW basis) & $68.9 \pm 0.56$ & $67.6 \pm 0.49$ & $68.5 \pm 0.53$ & $68.0 \pm 0.41$ & $68.7 \pm 0.40$ & NS & NS & NS & NS \\
\hline Digestive contents/SLW (\%) & $9.4 \pm 0.61$ & $10.8 \pm 0.54$ & $9.8 \pm 0.58$ & $9.5 \pm 0.45$ & $10.6 \pm 0.44$ & NS & NS & * & NS \\
\hline Skin/ELW (\%) & $9.6^{\mathrm{b}} \pm 0.18$ & $9.2^{\mathrm{b}} \pm 0.16$ & $10.8^{\mathrm{a}} \pm 0.17$ & $9.7 \pm 0.14$ & $10.0 \pm 0.13$ & $* * *$ & NS & $* * *$ & NS \\
\hline Head/ELW (\%) & $6.0^{\mathrm{ab}} \pm 0.09$ & $6.2^{\mathrm{a}} \pm 0.08$ & $5.8^{\mathrm{b}} \pm 0.08$ & $5.9^{\mathrm{b}} \pm 0.06$ & $6.1^{\mathrm{a}} \pm 0.06$ & $* *$ & $*$ & $* * *$ & NS \\
\hline Feet/ELW $(\%)$ & $3.2 \pm 0.05$ & $3.3 \pm 0.05$ & $3.3 \pm 0.05$ & $3.2^{\mathrm{b}} \pm 0.04$ & $3.4^{\mathrm{a}} \pm 0.04$ & NS & $* *$ & $* * *$ & NS \\
\hline KKCF/ELW (\%) & $1.2 \pm 0.14$ & $1.2 \pm 0.12$ & $1.4 \pm 0.13$ & $1.5^{\mathrm{a}} \pm 0.10$ & $1.0^{\mathrm{b}} \pm 0.10$ & NS & $* *$ & NS & NS \\
\hline Omental fat/ELW (\%) & $1.5 \pm 0.16$ & $1.5 \pm 0.14$ & $1.6 \pm 0.15$ & $1.8^{\mathrm{a}} \pm 0.12$ & $1.3^{\mathrm{b}} \pm 0.11$ & NS & $* *$ & $*$ & NS \\
\hline Mesenteric fat/ELW (\%) & $1.4 \pm 0.09$ & $1.6 \pm 0.08$ & $1.6 \pm 0.08$ & $1.7^{\mathrm{a}} \pm 0.06$ & $1.4^{\mathrm{b}} \pm 0.06$ & NS & $* *$ & NS & NS \\
\hline
\end{tabular}

Least-square means on the same row within genotype or sex without or with the same letter do not significantly differ $(P>0.05)$.

NS, not significant.

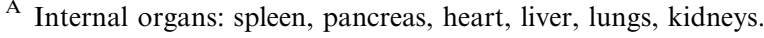

${ }^{*} P<0.05$

** $P<0.01$.

*** $P<0.001$ 
depots are considered to be late maturating, in relation to the ELW (Teixeira et al., 1995) they already demonstrate a preferential deposition in females. Despite the increase of internal fat of females the dressing percentage was not significantly affected by sex. Carcass measurements were clearly affected by genotype and HCW (Table 3). For example, genotype $\mathrm{B}$ had higher $(P<0.05)$ pelvis width and compactness index and lower $(P<0.001)$ side length and hind limb length when compared to $\mathrm{S}$ and $\mathrm{B} \times \mathrm{S}$ genotypes. Chest depth measurement of B carcasses was also significantly lower. These results suggest that carcasses of genotype $\mathrm{B}$, although shorter, have a more compact form. Carcass length measurement had a significant interaction with genotype and sex. Only genotype S females have inferior carcass length than males, being responsible for a significant interaction between genotype and sex. The effects of genotype and sex on the percentage of commercial joints adjusted for the same HCW are reported in Table 4. Car- casses from the B genotype had higher $(P<0.01)$ leg percentage than carcasses from $\mathrm{S} \times \mathrm{B}$. Carcasses from the $\mathrm{S}$ genotype had lower $(P<0.01)$ chump percentage and carcasses from B genotype had lower $(P<0.001)$ breast percentage. No differences $(P>0.05)$ were found between genotypes for ribs and neck percentages. Higher-priced joints $($ leg + loin + chump) were superior $(P<0.05)$ in $\mathrm{B}$ genotype compared to $\mathrm{S}$. Females had superior proportions of chump and higher-priced joints. Loin and shoulder proportions had a significant interaction between genotype and sex. Differences in joint percentages of goat carcasses from several breeds were reported by Tshabalala et al. (2003) and Sen et al. (2004).

With the exception of bone percentage, significant differences in carcass components were found between genotypes (Table 5). Serrana kid carcasses had significantly less muscle $(63 \%)$ and significantly more dissectible fat $(10.2 \%)$ than those from B $(66.1 \%$ and $11.9 \%$, respectively) or $\mathrm{S} \times \mathrm{B}$

Table 3

Least-square means $( \pm$ standard error) of carcass measurements of male and female kids from Serrana $(\mathrm{S})$, Bravia $(\mathrm{B})$ and Serrana $\times$ Bravia $(\mathrm{S} \times \mathrm{B})$ crossbred genotypes

\begin{tabular}{|c|c|c|c|c|c|c|c|c|c|c|}
\hline \multirow[t]{2}{*}{ Carcass measurements } & & \multicolumn{3}{|c|}{ Genotype (Gen) } & \multicolumn{2}{|l|}{ Sex } & \multicolumn{4}{|c|}{ Effects } \\
\hline & & B & $\mathrm{B} \times \mathrm{S}$ & $S$ & q & $\hat{o}$ & Gen & Sex & $\mathrm{HCW}$ & Gen $\times$ Sex \\
\hline Pelvis width $(\mathrm{cm})$ & & $15.3^{\mathrm{a}} \pm 0.43$ & $13.5^{\mathrm{b}} \pm 0.30$ & $13.8^{\mathrm{b}} \pm 0.35$ & $14.1 \pm 0.29$ & $14.2 \pm 0.26$ & * & NS & $* * *$ & NS \\
\hline Chest width $(\mathrm{cm})$ & & $11.6 \pm 0.25$ & $11.0 \pm 0.23$ & $11.1 \pm 0.24$ & $11.2 \pm 0.19$ & $11.3 \pm 0.18$ & NS & NS & $* * *$ & NS \\
\hline Chest depth $(\mathrm{cm})$ & & $18.0^{\mathrm{b}} \pm 0.18$ & $19.1^{\mathrm{a}} \pm 0.16$ & $19.1^{\mathrm{a}} \pm 0.16$ & $18.8 \pm 0.13$ & $18.6 \pm 0.13$ & $* * *$ & NS & $* * *$ & NS \\
\hline Side length $(\mathrm{cm})$ & & $42.6^{\mathrm{b}} \pm 0.47$ & $45.4^{\mathrm{a}} \pm 0.42$ & $44.7^{\mathrm{a}} \pm 0.46$ & $44.4 \pm 0.35$ & $44.1 \pm 0.34$ & *** & NS & $* * *$ & NS \\
\hline HCW: $1 / 2$ carcass length & & $11.8^{\mathrm{a}} \pm 0.13$ & $11.1^{\mathrm{b}} \pm 0.11$ & $11.3^{\mathrm{b}} \pm 0.12$ & $11.4 \pm 0.09$ & $11.4 \pm 0.09$ & $* *$ & NS & $* * *$ & NS \\
\hline Hind limb length $(\mathrm{cm})$ & & $24.1^{\mathrm{b}} \pm 0.31$ & $25.4^{\mathrm{a}} \pm 0.21$ & $25.4^{\mathrm{a}} \pm 0.21$ & $25.0 \pm 0.21$ & $24.9 \pm 0.18$ & ** & NS & $* * *$ & NS \\
\hline Carcass length $(\mathrm{cm})$ & 우 & $41.3^{\mathrm{bc}} \pm 0.44$ & $44.4^{\mathrm{a}} \pm 0.41$ & $41.8^{\mathrm{bc}} \pm 0.38$ & & & $* * *$ & NS & $* * *$ & $* * *$ \\
\hline & $\hat{0}$ & $41.0^{\mathrm{c}} \pm 0.39$ & $42.3^{\mathrm{bc}} \pm 0.37$ & $42.9^{\mathrm{ab}} \pm 0.42$ & & & & & & \\
\hline
\end{tabular}

Least-square means on the same row within genotype or sex without or with the same letter do not significantly differ $(P>0.05)$.

NS, not significant.

${ }^{*} P<0.05$.

** $P<0.01$.

*** $P<0.001$.

Table 4

Percentage contribution (least-square means \pm standard error) of anatomical joints to the carcasses of male and female kids from Serrana (S), Bravia (B) and Serrana $\times$ Bravia $(\mathrm{S} \times \mathrm{B})$ crossbred genotypes

\begin{tabular}{|c|c|c|c|c|c|c|c|c|c|c|}
\hline \multirow[t]{2}{*}{ Cuts $(\%)$} & & \multicolumn{3}{|c|}{ Genotype (Gen) } & \multicolumn{2}{|l|}{ Sex } & \multicolumn{4}{|c|}{ Effects } \\
\hline & & B & $\mathrm{B} \times \mathrm{S}$ & $S$ & q & $\hat{o}$ & Gen & Sex & $\mathrm{HCW}$ & Gen $\times$ Sex \\
\hline$\overline{\text { Leg }}$ & & $25.7^{\mathrm{a}} \pm 0.23$ & $24.6^{\mathrm{b}} \pm 0.21$ & $25.0^{\mathrm{ab}} \pm 0.23$ & $24.9 \pm 0.17$ & $25.3 \pm 0.17$ & ** & NS & NS & NS \\
\hline Chump & & $8.6^{a} \pm 0.15$ & $8.5^{\mathrm{a}} \pm 0.13$ & $7.9^{\mathrm{b}} \pm 0.14$ & $8.6^{\mathrm{a}} \pm 0.11$ & $8.1^{\mathrm{b}} \pm 0.11$ & $* *$ & $* * *$ & $* *$ & NS \\
\hline \multirow[t]{2}{*}{ Loin } & q & $11.8^{\mathrm{a}} \pm 0.38$ & $11.1^{\mathrm{ab}} \pm 0.22$ & $10.6^{\mathrm{ab}} \pm 0.21$ & & & $* * *$ & $*$ & $* * *$ & $*$ \\
\hline & ô & $10.3^{\mathrm{b}} \pm 0.22$ & $10.7^{\mathrm{ab}} \pm 0.20$ & $10.5^{\mathrm{b}} \pm 0.26$ & & & & & & \\
\hline Rib & & $6.5 \pm 0.11$ & $6.6 \pm 0.11$ & $6.7 \pm 0.11$ & $6.6 \pm 0.09$ & $6.5 \pm 0.09$ & NS & NS & NS & NS \\
\hline Anterior rib & & $5.4^{\mathrm{b}} \pm 0.10$ & $5.9^{\mathrm{a}} \pm 0.09$ & $5.6^{\mathrm{ab}} \pm 0.10$ & $5.7 \pm 0.08$ & $5.6 \pm 0.08$ & $* *$ & NS & $* *$ & NS \\
\hline \multirow[t]{2}{*}{ Shoulder } & 우 & $21.5^{\mathrm{bc}} \pm 0.39$ & $21.3^{\mathrm{c}} \pm 0.23$ & $23.0^{\mathrm{ab}} \pm 0.22$ & & & * & $* *$ & $* * *$ & $* *$ \\
\hline & $\hat{0}$ & $23.3^{\mathrm{a}} \pm 0.23$ & $22.3^{\mathrm{bc}} \pm 0.20$ & $22.7^{\mathrm{ab}} \pm 0.27$ & & & & & & \\
\hline Breast & & $10.8^{\mathrm{b}} \pm 0.21$ & $11.9^{\mathrm{a}} \pm 0.19$ & $12.0^{\mathrm{a}} \pm 0.21$ & $11.6 \pm 0.16$ & $11.5 \pm 0.15$ & $* * *$ & NS & $* *$ & NS \\
\hline Neck & & $9.8 \pm 0.21$ & $9.9 \pm 0.21$ & $9.3 \pm 0.21$ & $9.5 \pm 0.17$ & $9.8 \pm 0.17$ & NS & NS & NS & NS \\
\hline Higher-priced & & $44.6^{a} \pm 0.28$ & $43.9^{\mathrm{ab}} \pm 0.26$ & $43.3^{\mathrm{b}} \pm 0.28$ & $44.3^{\mathrm{a}} \pm 0.21$ & $43.6^{\mathrm{b}} \pm 0.21$ & t & . & NS & NS \\
\hline
\end{tabular}

Least-square means on the same row within genotype or sex without or with the same letter do not significantly differ $(P>0.05)$.

NS, not significant.

${ }^{*} P<0.05$.

** $P<0.01$.

*** $P<0.001$ 
Table 5

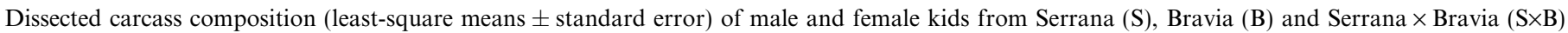
crossbred genotypes

\begin{tabular}{|c|c|c|c|c|c|c|c|c|c|}
\hline \multirow[t]{2}{*}{ Traits } & \multicolumn{3}{|c|}{ Genotype (Gen) } & \multicolumn{2}{|l|}{ Sex } & \multicolumn{4}{|c|}{ Effects } \\
\hline & B & $\mathrm{S} \times \mathrm{B}$ & $\mathrm{S}$ & q & $\hat{0}$ & Gen & Sex & $\mathrm{HCW}$ & Gen $\times$ Sex \\
\hline Muscle (\%) & $66.1^{\mathrm{a}} \pm 0.65$ & $65.5^{\mathrm{a}} \pm 0.58$ & $63.0^{\mathrm{b}} \pm 0.63$ & $64.8 \pm 0.48$ & $65.0 \pm 0.47$ & ** & NS & NS & NS \\
\hline Bone $(\%)$ & $20.4 \pm 0.32$ & $21.4 \pm 0.29$ & $21.1 \pm 0.31$ & $20.7 \pm 0.24$ & $21.2 \pm 0.23$ & NS & NS & $* * *$ & NS \\
\hline Subcutaneous fat $(\%)$ & $4.3^{\mathrm{a}} \pm 0.26$ & $3.4^{\mathrm{b}} \pm 0.23$ & $4.5^{\mathrm{a}} \pm 0.25$ & $4.1 \pm 0.19$ & $4.0 \pm 0.19$ & $* *$ & NS & $* *$ & NS \\
\hline Intermuscular fat $(\%)$ & $7.9^{b} \pm 0.62$ & $8.0^{\mathrm{b}} \pm 0.56$ & $10.2^{\mathrm{a}} \pm 0.60$ & $9.0 \pm 0.46$ & $8.4 \pm 0.45$ & * & NS & NS & NS \\
\hline Dissectible fat $(\%)$ & $11.9^{\mathrm{b}} \pm 0.72$ & $11.4^{\mathrm{b}} \pm 0.73$ & $15.0^{\mathrm{a}} \pm 0.70$ & $13.0 \pm 0.59$ & $12.4 \pm 0.58$ & $* *$ & NS & NS & NS \\
\hline Muscle:bone & $3.3^{\mathrm{a}} \pm 0.05$ & $3.1^{\mathrm{b}} \pm 0.05$ & $3.0^{\mathrm{b}} \pm 0.05$ & $3.1 \pm 0.04$ & $3.1 \pm 0.04$ & $* *$ & NS & * & NS \\
\hline
\end{tabular}

Least-square means on the same row within genotype or sex without or with the same letter do not significantly differ $(P>0.05)$.

NS, not significant.

* $P<0.05$.

** $P<0.01$.

*** $P<0.001$.

crosses $(65.5 \%$ and $11.4 \%$, respectively). Serrana had the most intermuscular fat and $\mathrm{S} \times \mathrm{B}$ had the lowest subcutaneous fat content. As body composition is closely related to maturity stage (McClelland, Bonaiti, \& Taylor, 1976; Wood, MacFie, Pomeroy, \& Twinn, 1980) these results suggest that at the same adjusted HCW kids from the S genotype were more mature compared to those of B and $\mathrm{BxS}$. Several studies reported significant variations between goat genotypes in the percentage of muscle (Dhanda et al., 1999c; Mahgoub \& Lu, 1998; Oman et al., 2000). However, some of these differences were related to the stage of maturity rather than breed because the genotypes compared differs in mature body size. Previous studies conducted with the adult females from $\mathrm{S}, \mathrm{S} \times \mathrm{B}$ and $\mathrm{B}$ genotypes reared under extensive management in the Barroso highlands did not find significant differences in mature live weight (Santos et al., 2002). The low variation observed among genotypes for carcass bone proportion is consistent with the observation of Pralomkarn, Saithanoo, Kochapakdee, and Norton (1995). Values found in this study were similar to those observed in pelvic limb $(21.4 \%)$ by Todaro et al. (2004) in Nebrodi kids. Muscle/bone ratio was superior $(P<0.05)$ for the B genotype. Higher values of muscle/ bone ratio are associated with a better conformation in lambs (Hopkins, Fogarty, \& Menzis, 1997) which is in agreement with kids' carcass measurements. The effect of $\mathrm{HCW}$ was significant for bone and subcutaneous fat contents and muscle/bone ratio. No significant differences in carcass composition were observed between male and female kid and interactions between genotype and sex were not significant.

\subsection{Meat quality attributes}

Characteristics of the LTL and GB muscles associated with meat quality are given in Table 6 . Meat quality attributes were clearly affected by genotype (Table 6). Kids from $\mathrm{S} \times \mathrm{B}$ and $\mathrm{S}$ genotypes had higher muscle $\mathrm{pH}_{24}(5.89$ and 5.88, respectively) than the B genotype (5.67), but was in the accepted quality range (Hedrick, Aberle, Forrest, Judge, \& Merkel, 1994) and similar to those found by Marichal et al. (2003) and Dhanda et al. (1999b). However, compared to other species, high ultimate $\mathrm{pH}$ values $(>6.00)$ for goat muscles are prevalent in the studies reviewed by Webb et al. (2005). Previous studies reported significant variations between different goat genotypes in ultimate $\mathrm{pH}$ evaluated in LTL muscle (Dhanda, Taylor, \& Murray, 2003a; Kadim et al., 2003). According to Dhanda et al. (2003a) the significantly higher muscle $\mathrm{pH}$ found in Boer $\times$ Feral kids (5.93) could either be due to a breed characteristic or due to the differences in their response to pre-slaughter handling.

Muscle colour is extremely important in suckling kids' production whose carcasses should be pale or pink. Muscles colour defined by coordinates $L^{*}$ (lightness) and $a^{*}$ (redness) was affected by genotype (Table 6). The $\mathrm{S} \times \mathrm{B}$ genotype displayed higher $a^{*}$ values (which vary in relation to haem pigment conten), and $L^{*}$ and $b^{*}$ values showed a significant interaction between genotype and sex. Both sexes from $\mathrm{B}$ and $\mathrm{S}$ genotypes had significantly lighter muscles (near to 50) than females of $\mathrm{S} \times \mathrm{B}$ genotype (44.1). Total muscle pigment concentrations were also influenced by genotype with $\mathrm{S} \times \mathrm{B}$ genotype muscles having significantly $(P<0.05)$ higher total pigment $(1.35 \mathrm{mg} / \mathrm{g})$ which is closely related to the higher relative redness $\left(a^{*}\right)$ of the $\mathrm{S} \times \mathrm{B}$ genotype muscles.

In the present experiment, a lower cooking loss for the $\mathrm{S}$ genotype $(10.2 \%)$ compared to the B genotype (12.2\%) might be due to higher ultimate $\mathrm{pH}$ values. Several authors have reported higher cooking losses (Dhanda et al., 1999b; Johnson et al., 1995; Sen et al., 2004) for goat muscles. Some variations in cooking losses between studies can be attributed to differences in length and cooking temperatures, ultimate $\mathrm{pH}$ and the muscle cuts used. Breed differences in cooking yield have also been reported by Schönfeldt et al. (1993) and Dhanda et al. (1999b).

Tenderness, evaluated by the maximum shear force necessary to cut the meat perpendicular to the fibres, displayed a significant interaction between genotype and sex (Table 6). Muscle shear force values from males of the $S$ genotype was higher $\left(9.8 \mathrm{~kg} / \mathrm{cm}^{2}\right)$ than for muscles from males of $\mathrm{S} \times \mathrm{B}$ genotype $\left(7.5 \mathrm{~kg} / \mathrm{cm}^{2}\right)$. These values were high com- 
Table 6

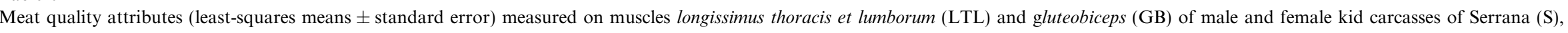
Bravia $(\mathrm{B})$ and Serrana $\times$ Bravia $(\mathrm{S} \times \mathrm{B})$ crossbred genotypes

\begin{tabular}{|c|c|c|c|c|c|c|c|c|c|c|c|c|c|}
\hline \multirow[t]{2}{*}{ Meat quality attributes } & & \multicolumn{3}{|c|}{ Genotype (Gen) } & \multicolumn{2}{|l|}{$\underline{\text { Sex }}$} & & \multicolumn{2}{|c|}{ Muscle (Mus) } & \multicolumn{4}{|c|}{ Effects } \\
\hline & & $\mathrm{B}$ & $\mathrm{S} \times \mathrm{B}$ & $\mathrm{S}$ & q & $\hat{0}$ & & LTL & GB & Gen & Sex & Mus & Gen $\times$ Sex \\
\hline $\mathrm{pH}_{24}$ & & $5.67^{\mathrm{b}} \pm 0.03$ & $5.89^{\mathrm{a}} \pm 0.03$ & $5.88^{\mathrm{a}} \pm 0.03$ & $5.79 \pm 0.02$ & $5.83 \pm 0.02$ & & $5.76^{\mathrm{b}} \pm 0.02$ & $5.87^{\mathrm{a}} \pm 0.02$ & $* * *$ & NS & ** & NS \\
\hline Lightness $\left(L^{*}\right)$ & $\begin{array}{l}\text { q } \\
\hat{0}\end{array}$ & $\begin{array}{l}49.1^{\mathrm{a}} \pm 0.89 \\
48.7^{\mathrm{a}} \pm 0.89\end{array}$ & $\begin{array}{r}44.1^{\mathrm{b}} \pm 1.02 \\
46.9^{\mathrm{ab}} \pm 0.87\end{array}$ & $\begin{array}{l}49.9^{\mathrm{a}} \pm 0.85 \\
48.2^{\mathrm{a}} \pm 0.89\end{array}$ & & & & $47.2 \pm 0.51$ & $48.3 \pm 0.52$ & $* * *$ & NS & NS & * \\
\hline Redness $\left(a^{*}\right)$ & & $16.4^{\mathrm{b}} \pm 0.29$ & $18.0^{\mathrm{a}} \pm 0.31$ & $16.4^{\mathrm{b}} \pm 0.28$ & $17.0 \pm 0.24$ & $16.8 \pm 0.23$ & & $17.0 \pm 0.23$ & $16.8 \pm 0.24$ & *** & NS & NS & NS \\
\hline Yellowness $\left(b^{*}\right)$ & $\begin{array}{l}q \\
+ \\
0\end{array}$ & $\begin{array}{l}5.9 \pm 0.21 \\
5.7 \pm 0.21\end{array}$ & $\begin{array}{l}5.5 \pm 0.24 \\
6.0 \pm 0.21\end{array}$ & $\begin{array}{l}5.8 \pm 0.20 \\
5.2 \pm 0.21\end{array}$ & & & & $5.2^{b} \pm 0.12$ & $6.2^{\mathrm{a}} \pm 0.13$ & NS & NS & $* * *$ & * \\
\hline Total pigment (mg/g) & & $0.97^{\mathrm{b}} \pm 0.06$ & $1.35^{\mathrm{a}} \pm 0.06$ & $1.08^{\mathrm{b}} \pm 0.06$ & $1.19 \pm 0.05$ & $1.08 \pm 0.05$ & & $1.13 \pm 0.05$ & $1.14 \pm 0.05$ & ${ }^{* * *}$ & NS & NS & NS \\
\hline Cooking loss (\%) & & $12.2^{\mathrm{a}} \pm 0.50$ & $10.9^{\mathrm{ab}} \pm 0.50$ & $10.2^{\mathrm{b}} \pm 0.48$ & $11.4 \pm 0.41$ & $10.8 \pm 0.40$ & & $11.1 \pm 0.41$ & $11.1 \pm 0.40$ & * & NS & NS & NS \\
\hline Shear force $\left(\mathrm{kg} / \mathrm{cm}^{2}\right)$ & $\begin{array}{l}q \\
+ \\
0\end{array}$ & $\begin{array}{l}9.4^{\mathrm{ab}} \pm 0.51 \\
9.1^{\mathrm{ab}} \pm 0.52\end{array}$ & $\begin{array}{r}9.5^{\mathrm{ab}} \pm 0.54 \\
7.5^{\mathrm{b}} \pm 0.48\end{array}$ & $\begin{array}{r}8.7^{\mathrm{ab}} \pm 0.48 \\
9.8^{\mathrm{a}} \pm 0.52\end{array}$ & & & & $7.8^{b} \pm 0.30$ & $10.2^{\mathrm{a}} \pm 0.29$ & NS & NS & $* * *$ & * \\
\hline Intramuscular fat (\%DM) & $\begin{array}{l}0 \\
+ \\
0\end{array}$ & $\begin{array}{l}5.1^{\mathrm{b}} \pm 0.44 \\
4.1^{\mathrm{b}} \pm 0.44\end{array}$ & $\begin{array}{l}5.5^{b} \pm 0.47 \\
4.9^{b} \pm 0.42\end{array}$ & $\begin{array}{l}7.8^{\mathrm{a}} \pm 0.42 \\
5.0^{\mathrm{b}} \pm 0.44\end{array}$ & & & & $4.4^{b} \pm 0.25$ & $6.4^{\mathrm{a}} \pm 0.25$ & *** & $* * *$ & $* * *$ & * \\
\hline Total collagen $(\% \mathrm{DM})$ & & $2.5^{\mathrm{b}} \pm 0.09$ & $2.7^{\mathrm{ab}} \pm 0.09$ & $3.1^{\mathrm{a}} \pm 0.09$ & & & $\begin{array}{l}\text { q } \\
\hat{0}\end{array}$ & $\begin{array}{l}2.1^{\mathrm{c}} \pm 0.11 \\
2.2^{\mathrm{c}} \pm 0.10\end{array}$ & $\begin{array}{l}3.1^{\mathrm{b}} \pm 0.11 \\
3.7^{\mathrm{a}} \pm 0.11\end{array}$ & $\underset{* * *}{\text { Gen }}$ & $\underset{* *}{\operatorname{Sex}}$ & $\underset{* * *}{\operatorname{Mus}}$ & $\underset{*}{\operatorname{Mus} \times \operatorname{Sex}}$ \\
\hline $\begin{array}{l}\text { Collagen solubility ( } \% \\
\text { total) }\end{array}$ & & $8.7^{\mathrm{a}} \pm 0.34$ & $7.9^{\mathrm{ab}} \pm 0.34$ & $6.7^{b} \pm 0.38$ & $7.6 \pm 0.29$ & $7.9 \pm 0.27$ & 0 & $8.4^{\mathrm{a}} \pm 0.28$ & $7.1^{b} \pm 0.28$ & ${ }^{* * *}$ & NS & $* *$ & NS \\
\hline
\end{tabular}

Least-square means on the same row within genotype, sex or muscle without or with the same letter do not significantly differ $(P>0.05)$

DM, dry matter.

NS, not significant.

* $P<0.05$.

${ }^{* *} P<0.01$.

*** $P<0.001$. 
pared to other studies (Babiker, El Khider, \& Shafie, 1990; Dhanda et al., 2003a), however, similar values $\left(8.5 \mathrm{~kg} / \mathrm{cm}^{2}\right)$ were reported in Angora and Spanish goat breeds (Riley, Savell, Johnson, Smith, \& Shelton, 1989). Shear force values reported for goat meat vary considerably, depending on factors such as the treatment of the animals prior to slaughter and of the carcass post-mortem, the sampled muscle and method of sample preparation (Webb et al., 2005).

Intramuscular fat muscle contents were within $4.1-7.8 \%$ DM range for the three genotypes and there was significant interaction between genotype and sex for this variable (Table 6). Muscles from the $\mathrm{S}$ genotype females had significantly higher intramuscular fat $(7.8 \% \mathrm{DM})$ compared to the other sex and genotypes (4.1-5.5\% DM). Muscles from the $\mathrm{S}$ genotype had significantly higher total collagen $(3.1 \%$ $\mathrm{DM})$ and lower collagen solubility $(6.7 \%$ total $)$ compared to muscles from the B genotype $(2.5 \%$ and $8.7 \%$, respectively). These results are consistent with differences of maturity between genotypes because collagen solubility decreases with increasing maturity (Cross et al., 1973). Collagen determinations were also influenced by the type of muscle. Total muscle collagen ( $\% \mathrm{DM})$ showed a significant interaction between sex and muscle. The GB muscle from males had higher total collagen than that from females. Total collagen of LTL muscle did not differ between the sexes and for both sexes GB muscles had higher total collagen than LTL muscles. Collagen solubility was higher in LTL $(8.4 \%)$ than in GB $(7.1 \%)$ and is closely related to the lower shear force needed to cut the muscle LTL.

LTL sarcomere length varied between 1.71 and $1.90 \mu \mathrm{m}$ (Table 7) and the $\mathrm{S} \times \mathrm{B}$ genotype LTL had greater $(P<0.05)$ sarcomere length than the $\mathrm{B}$ genotype. Considering that at rest sarcomere length is $2 \mu \mathrm{m}$ (Ouali, Lepetit, Touraille, \& Kopp, 1994) and kid carcasses have thin subcutaneous fat cover these results may suggest cold-shortening of the LTL. The ultimate $\mathrm{pH}, b^{*}$ coordinate, shear force and intramuscular fat content were affected by type of muscle. These meat quality characteristics were significantly lower in LTL than GB. Variations among muscles in $\mathrm{pH}_{24}$ might be explained by the fact that muscles differ in red and white fibre type proportions and therefore, they also differ in energy metabolism patterns in both ant- and post-mortem (Klont, Brocks, \& Eikelenboom, 1998).

The sex effect was not significant for the majority of meat quality attributes; although there were some signifi- cant interactions between genotype and sex and between muscle and sex, as described in preceding points (Table 6).

\subsection{Fatty acid composition}

The results for total FA and FA composition of LTL and GB muscles are presented in Table 8. Oleic (C18:1), palmitic $(\mathrm{C} 16: 0)$ and stearic $(\mathrm{C} 18: 0)$ acids comprised the largest proportions of $\mathrm{FA}$ in the muscle tissue $(80.7 \%$ in GB muscle and $82.4 \%$ in LTL) with oleic acid being the most abundant. These results are in agreement with other goat studies (Dhanda et al., 1999d; Mahgoub et al., 2002; Johnson et al., 1995; Mahgoub et al., 2002) and are also comparable to those reported in other red meat animal species (Banskalieva et al., 2000).

There was significant interaction between genotype and sex for total FA with females of $\mathrm{S}$ genotype displaying higher total FA proportion (Table 8). Genotype had a clear influence on intramuscular fatty acid composition. Capric (C10:0), palmitic (C16:0), oleic (C18:1) and C20:0 were the only FA not affected by genotype. Kids of the S genotype had higher proportions of myristic acid (C14:0) and a lower stearic acid (C18:0) when compared with B and $\mathrm{S} \times \mathrm{B}$ genotypes. The proportion of $\mathrm{C} 16: 1$ and $\mathrm{C} 17: 0$ were, respectively, higher and lower for the $\mathrm{S}$ genotype, compared to the B genotype. Kids of the $\mathrm{S} \times \mathrm{B}$ genotype showed intermediate values for these $\mathrm{FA}$, and higher proportions of linoleic acid $(6.01 \%)$ than the genotype $\mathrm{S}(3.98 \%)$. It is generally accepted that the FA profile of adipose depots of suckling kids is related to that of maternal milk which is rich in SFA, especially palmitic (C16:0) and stearic (C18:0) acids (Zygoyiannis et al., 1992). Dhanda et al. (1999d) found significant differences between genotypes in individual FA proportion of adipose tissue of the Capretto group, and these variations were attributed to the amount of milk received by the kids and the milk fatty acid composition. In the present study, the proportions of desirable fatty acids (DFA) ranged within 60.5-68.8\%. Other authors, for the same muscles in other goat breeds, reported $61.3-79.8 \%$ of DFA (Matsuoka, Furokawa, \& Takahashi, 1997; Park \& Washington, 1993; Potchoiba, Lu, Pinkerton, \& Sahlu, 1990). Recently reported DFA in the pelvic limb fat of suckling kids were $49.4 \%$ and $53.1 \%$ for Girgentana kids (Todaro et al., 2002) slaughtered at two different ages ( 25 and 35 days, respectively) and $46.3 \%$ for Nebrodi kids slaughtered at 47 days of age

Table 7

Analysis of variance and least-squares means ( \pm standard error) of longissimus thoracis et lumborum (LTL) muscle sarcomere length $(\mu \mathrm{m})$ of male and female kids carcasses of Serrana (S), Bravia (B) and Serrana $\times$ Bravia $(\mathrm{S} \times \mathrm{B})$ crossbred genotypes

\begin{tabular}{|c|c|c|c|c|c|c|c|c|}
\hline & \multicolumn{3}{|c|}{ Genotype (Gen) } & \multicolumn{2}{|l|}{ Sex } & \multicolumn{3}{|c|}{ Effects } \\
\hline & $\mathrm{B}$ & $\mathrm{S} \times \mathrm{B}$ & $\mathrm{S}$ & q & $\hat{0}$ & Gen & Sex & Gen $\times$ Sex \\
\hline Sarcomere length $(\mu \mathrm{m})$ & $1.71^{\mathrm{b}} \pm 0.05$ & $1.90^{\mathrm{a}} \pm 0.05$ & $1.74^{\mathrm{ab}} \pm 0.05$ & $1.79 \pm 0.04$ & $1.79 \pm 0.04$ & $*$ & NS & NS \\
\hline
\end{tabular}

Least-square means on the same row within genotype without or with the same letter do not significantly differ $(P>0.05)$.

NS, not significant.

${ }^{*} P<0.05$. 
Table 8

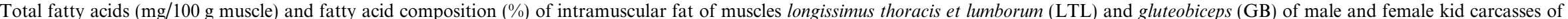
Serrana (S), Bravia $(\mathrm{B})$ and Serrana $\times$ Bravia $(\mathrm{S} \times \mathrm{B})$ crossbred genotypes

\begin{tabular}{|c|c|c|c|c|c|c|c|c|c|c|c|c|}
\hline & & \multicolumn{3}{|c|}{ Genotype (Gen) } & \multicolumn{2}{|l|}{ Sex } & \multicolumn{2}{|l|}{ Muscle (Mus) } & \multicolumn{4}{|c|}{ Effects } \\
\hline & & $\mathrm{B}$ & $\mathrm{S} \times \mathrm{B}$ & $\mathrm{S}$ & q & $\hat{0}$ & LTL & GB & Gen & Sex & Mus & Gen $\times$ Sex \\
\hline Total FA & $\begin{array}{l}q \\
+ \\
0\end{array}$ & $\begin{array}{l}898^{b} \pm 84.1 \\
819^{b} \pm 84.1\end{array}$ & $\begin{array}{l}1140^{\mathrm{b}} \pm 84.1 \\
1029^{\mathrm{b}} \pm 89.0\end{array}$ & $\begin{array}{r}1578^{\mathrm{a}} \pm 84.1 \\
997^{\mathrm{b}} \pm 84.1\end{array}$ & & & $910^{\mathrm{b}} \pm 51.9$ & $1241^{\mathrm{a}} \pm 52.8$ & *** & $* * *$ & $* * *$ & ** \\
\hline $\mathrm{C}_{10: 0}$ & & $0.15 \pm 0.07$ & $0.21 \pm 0.04$ & $0.31 \pm 0.04$ & $0.28^{\mathrm{a}} \pm 0.03$ & $0.16^{\mathrm{b}} \pm 0.05$ & $0.27 \pm 0.04$ & $0.17 \pm 0.04$ & NS & * & NS & NS \\
\hline $\mathrm{C}_{12: 0}$ & $\begin{array}{l}q \\
\hat{0}\end{array}$ & $\begin{array}{r}0.61^{\mathrm{abc}} \pm 0.13 \\
0.33^{\mathrm{c}} \pm 0.13\end{array}$ & $\begin{array}{l}0.98^{\mathrm{ab}} \pm 0.13 \\
0.47^{\mathrm{bc}} \pm 0.13\end{array}$ & $\begin{array}{r}0.95^{\mathrm{ab}} \pm 0.13 \\
1.08^{\mathrm{a}} \pm 0.13\end{array}$ & & & $0.74 \pm 0.08$ & $0.73 \pm 0.08$ & $* * *$ & * & NS & * \\
\hline $\mathrm{C}_{14: 0}$ & & $5.42^{\mathrm{b}} \pm 0.40$ & $6.29^{\mathrm{b}} \pm 0.41$ & $8.57^{\mathrm{a}} \pm 0.40$ & $7.40^{\mathrm{a}} \pm 0.32$ & $6.12^{\mathrm{b}} \pm 0.33$ & $6.70 \pm 0.32$ & $6.82 \pm 0.33$ & $* * *$ & $* *$ & NS & NS \\
\hline $\mathrm{C}_{15: 0}$ & $\begin{array}{l}\text { o } \\
\hat{0}\end{array}$ & $\begin{array}{r}0.56^{\mathrm{c}} \pm 0.05 \\
0.60^{\mathrm{bc}} \pm 0.05\end{array}$ & $\begin{aligned} 0.76^{\mathrm{ab}} & \pm 0.05 \\
0.52^{\mathrm{c}} & \pm 0.05\end{aligned}$ & $\begin{aligned} 0.67^{\mathrm{abc}} & \pm 0.05 \\
0.81^{\mathrm{a}} & \pm 0.05\end{aligned}$ & & & $0.64 \pm 0.03$ & $0.67 \pm 0.03$ & $* *$ & NS & NS & $* * *$ \\
\hline$C_{16: 0}$ & & $25.60 \pm 0.90$ & $25.68 \pm 0.93$ & $26.65 \pm 0.90$ & $26.46 \pm 0.74$ & $25.50 \pm 0.75$ & $26.09 \pm 0.74$ & $25.86 \pm 0.75$ & NS & NS & NS & NS \\
\hline$C_{16: 1}$ & & $2.77^{\mathrm{b}} \pm 0.23$ & $3.32^{\mathrm{ab}} \pm 0.24$ & $4.00^{\mathrm{a}} \pm 0.23$ & $3.63 \pm 0.19$ & $3.10 \pm 0.19$ & $3.26 \pm 0.19$ & $3.47 \pm 0.19$ & * & NS & NS & NS \\
\hline $\mathrm{C}_{17: 0}$ & & $1.70^{\mathrm{a}} \pm 0.07$ & $1.53^{\mathrm{ab}} \pm 0.08$ & $1.39^{\mathrm{b}} \pm 0.07$ & $1.52 \pm 0.06$ & $1.56 \pm 0.06$ & $1.53 \pm 0.06$ & $1.55 \pm 0.06$ & * & NS & NS & NS \\
\hline $\mathrm{C}_{18: 0}$ & & $18.25^{\mathrm{a}} \pm 0.82$ & $18.00^{\mathrm{a}} \pm 0.84$ & $14.34^{\mathrm{b}} \pm 0.82$ & $16.57 \pm 0.67$ & $17.15 \pm 0.68$ & $16.43 \pm 0.67$ & $17.29 \pm 0.68$ & $* *$ & NS & NS & NS \\
\hline$C_{18: 1}$ & & $39.86 \pm 1.43$ & $37.46 \pm 1.47$ & $38.87 \pm 1.43$ & $38.20 \pm 1.17$ & $39.26 \pm 1.19$ & $39.90 \pm 1.17$ & $37.56 \pm 1.19$ & NS & NS & NS & NS \\
\hline $\mathrm{C}_{18: 2}$ & & $5.18^{\mathrm{ab}} \pm 0.49$ & $6.01^{\mathrm{a}} \pm 0.50$ & $3.98^{\mathrm{b}} \pm 0.49$ & $4.34^{\mathrm{b}} \pm 0.40$ & $5.77^{\mathrm{a}} \pm 0.41$ & $4.35^{\mathrm{b}} \pm 0.40$ & $5.76^{\mathrm{a}} \pm 0.41$ & $*$ & * & * & NS \\
\hline $\mathrm{C}_{20: 0}$ & & $0.16 \pm 0.01$ & $0.18 \pm 0.01$ & $0.14 \pm 0.01$ & $0.16 \pm 0.01$ & $0.16 \pm 0.01$ & $0.16 \pm 0.01$ & $0.16 \pm 0.01$ & NS & NS & NS & NS \\
\hline DFA $(\%)$ & $\begin{array}{l}q \\
+ \\
0\end{array}$ & $\begin{array}{l}65.51^{\mathrm{a}} \pm 1.80 \\
66.61^{\mathrm{a}} \pm 1.80\end{array}$ & $\begin{array}{l}60.82^{\mathrm{a}} \pm 1.80 \\
68.75^{\mathrm{a}} \pm 1.91\end{array}$ & $\begin{array}{l}61.89^{\mathrm{a}} \pm 1.80 \\
60.48^{\mathrm{b}} \pm 1.80\end{array}$ & & & $63.95 \pm 1.04$ & $64.08 \pm 1.06$ & * & NS & NS & * \\
\hline PUFA:SFA & & $0.11^{\mathrm{ab}} \pm 0.01$ & $0.12^{\mathrm{a}} \pm 0.01$ & $0.08^{\mathrm{b}} \pm 0.01$ & $0.09^{\mathrm{b}} \pm 0.01$ & $0.12^{\mathrm{a}} \pm 0.01$ & $0.09^{\mathrm{b}} \pm 0.01$ & $0.12^{\mathrm{a}} \pm 0.01$ & * & $*$ & * & NS \\
\hline UFA (\%) & & $47.81 \pm 1.67$ & $46.79 \pm 1.72$ & $46.85 \pm 1.67$ & $46.17 \pm 1.36$ & $48.13 \pm 1.39$ & $47.51 \pm 1.36$ & $46.78 \pm 1.39$ & NS & NS & NS & NS \\
\hline UFA:SFA & & $0.95 \pm 0.05$ & $0.93 \pm 0.05$ & $0.89 \pm 0.05$ & $0.90 \pm 0.04$ & $0.95 \pm 0.04$ & $0.92 \pm 0.04$ & $0.92 \pm 0.04$ & NS & NS & NS & NS \\
\hline$(\mathrm{C} 18: 0+\mathrm{C} 18: 1): \mathrm{C} 16: 0$ & $\begin{array}{l}q \\
+ \\
0\end{array}$ & $\begin{array}{l}2.29^{\mathrm{a}} \pm 0.12 \\
2.34^{\mathrm{a}} \pm 0.12\end{array}$ & $\begin{array}{l}2.03^{\mathrm{a}} \pm 0.12 \\
2.50^{\mathrm{a}} \pm 0.13\end{array}$ & $\begin{array}{l}2.10^{\mathrm{a}} \pm 0.12 \\
1.94^{\mathrm{b}} \pm 0.12\end{array}$ & & & $2.19 \pm 0.07$ & $2.21 \pm 0.07$ & * & NS & NS & * \\
\hline
\end{tabular}

DFA (desirable fatty acids $=$ C18:0 + mono-unsaturated fatty acids + poly-unsaturated fatty acids); UFA, unsaturated fatty acids; PUFA, poly-unsaturated fatty acids

Least-square means on the same row within genotype, sex or muscle without or with the same letter do not significantly differ $(P>0.05)$.

NS, not significant.

${ }^{*} P<0.05$

** $P<0.01$

${ }^{* * *} P<0.001$. 
(Todaro et al., 2004). The three fatty acids that represent the majority of muscle fat have different implications for consumer health, only C16:0 increases blood cholesterol, whereas C18:0 has no effect and C18:1 decreases blood cholesterol content (Bonamone \& Grundy, 1988). For this reason Banskalieva et al. (2000) suggest that the ratio of $(\mathrm{C} 18: 0+\mathrm{C} 18: 1): \mathrm{C} 16: 0$ could be useful in describing the potential health effects of different lipid types. In different goat muscles this ratio varied between 1.37 in longissimus dorsi (Potchoiba et al., 1990) and 3.64 in brachii muscle (Sauvant, Bas, \& Morand-Fehr, 1979). In the present study this ratio was 2.20 (average of LTL and GB), which was similar to that reported for Nebrodi (Todaro et al., 2004) and lower than in Maltese (Vicenti, Ragni, Ginnico, Vonghia, \& Zezza, 2001) breeds, both slaughtered at 47 days of age.

In the present study, muscles from males of the $\mathrm{S}$ genotype displayed lower DFA proportion and lower $(\mathrm{C} 18: 0+\mathrm{C} 18: 1): \mathrm{C} 16: 0$ ratio. The ratio PUFA:SFA was higher in $\mathrm{S} \times \mathrm{B}$ genotype compared to $\mathrm{S}$ genotype. UFA and UFA:SFA ratio were not affected by genotype. Other authors found differences among breeds in UFA contents (Dhanda, Taylor, \& Murray, 2003b; Dhanda et al., 1999d; Tshabalala et al., 2003) and UFA:SFA ratio (Dhanda et al., 2003b).

There were significant differences between sexes in C10:0, C14:0 and C18:2 FA proportions and in the PUFA:SFA ratio (Table 8). Females displayed higher C10:0 and C14:0 values and lower C18:2 and PUFA:SFA values. Johnson et al. (1995) and Matsuoka et al. (1997) using different breeds and tested meat noted PUFA:SFA ratio greater in male animals compared with females.

Type of muscle affected total FA, C18:2 proportions and PUFA:SFA ratio, with GB muscle displaying significantly $(P<0.05)$ higher total FA proportions, $\mathrm{C} 18: 2$ and higher PUFA:SFA ratio (Table 8). The results of the present study correspond with data of Velasco, Cañeque, Lauzurica, Pérez, and Huidobro (2004) with lambs longissimus thoracis and quadriceps femoris muscles. Differences in muscle fibre type between muscles are reflected in differences in fatty acid composition of PUFA. "Red" oxidative fibres have a higher proportion of phospholipids than the white ones and therefore, a higher percentage of PUFA (Wood et al., 2003). Similarly, Enser et al. (1998) in beef found that PUFA:SFA ratio in relatively white longissimus muscle (0.08) is lower compared with the gluteobiceps muscle $(0.12)$ due to higher concentrations of most PUFA in red muscles.

\section{Conclusion}

Genotype was associated with differences in carcass composition and meat quality traits, despite the narrow weight range of PGI "Cabrito de Barroso". In the present study, Serrana genotype was more mature, which caused variations in fat composition, either quantitatively or qualitatively. Meat quality traits, such as total collagen and col- lagen solubility followed the same tendency. Sex had no effect on the composition of the dissected carcass but females deposited more internal fat. The effect of sex on meat quality traits as well as on fatty acid composition was sometimes detectable with significant interaction with genotype. Relatively to meat quality attributes it seems that in order to reduce muscle cold-shortening and improve meat tenderness, kid carcasses should be chilled in a way to avoid cold-shortening or should be electrically stimulated before chilling in order to retain the tenderness of meat.

\section{References}

AOAC (1990). In Official methods of analysis (15th ed.). Hidroxiprolin in meat and meat products (Vol. 1). Virginia: Association of Official Analytical Chemists, Inc.

Babiker, S. A., El Khider, I. A., \& Shafie, S. A. (1990). Chemical composition and quality attributes of goat meat and lamb. Meat Science, 28, 273-277.

Banskalieva, V., Sahlu, T., \& Goetsch, A. L. (2000). Fatty acid composition of goat muscles and fat depots: a review. Small Ruminant Research, 37, 255-268.

Boccard, R., Buchter, L., Casteels, E., Cosentino, E., Dransfield, E., Hood, D. E., et al. (1981). Procedures for measuring meat quality characteristics in beef production experiments. Report of a working group in the Commission of the European Communities' (CEC) beef production research programme. Livestock Production Science, 8, 385-397.

Bonamone, A., \& Grundy, S. M. (1988). Effect of dietary stearic acid on plasma cholesterol and lipoprotein levels. New England Journal of Medicine, 318, 1244-1247.

Cross, H. R., Carpenter, Z. L., \& Smith, G. C. (1973). Effects of intramuscular collagen and elastin on bovine muscle tenderness. Journal of Food Science, 38, 998-1003.

Cross, H. R., West, R. L., \& Dutson, T. R. (1981). Comparison of methods for measuring sarcomere length in beef semitendinosus muscle. Meat Science, 5, 261-266.

Dhanda, J. S., Taylor, D. G., \& Murray, P. J. (2003a). Part 1. Growth, carcass and meat quality parameters of male goats: effects of genotype and liveweight at slaughter. Small Ruminant Research, 50, $57-66$.

Dhanda, J. S., Taylor, D. G., \& Murray, P. J. (2003b). Part 2. Carcass composition and fatty acid profiles of adipose tissue of male goats: effects of genotype and liveweight at slaughter. Small Ruminant Research, 50, 67-74.

Dhanda, J. S., Taylor, D. G., McCosker, J. E., \& Murray, P. J. (1999a). The influence of goat genotype on the production of Capretto and Chevon carcasses. 1. Growth and carcass characteristics. Meat Science, 52, 355-361.

Dhanda, J. S., Taylor, D. G., Murray, P. J., \& McCosker, J. E. (1999b). The influence of goat genotype on the production of Capretto and Chevon carcasses. 2. Meat quality. Meat Science, 52, 363-367.

Dhanda, J. S., Taylor, D. G., McCosker, J. E., \& Murray, P. J. (1999c). The influence of goat genotype on the production of Capretto and Chevon carcasses. 3. Dissected carcass composition. Meat Science, 52, 369-374

Dhanda, J. S., Taylor, D. G., Murray, P. J., \& McCosker, J. E. (1999d). The influence of goat genotype on the production of Capretto and Chevon carcasses. 4. Chemical composition of muscle and fatty acid profiles of adipose tissue. Meat Science, 52, 375-379.

Doney, J. M., Smith, A. D. M., Sim, D. A., \& Zygoyiannis, D. (1984). Milk and herbage intake of suckled and artificially reared lambs at pasture as influenced by lactacion pattern. Animal Production, 38, 191-199. 
Enser, M., Hallet, K. G., Hewett, B., Fursey, G. A. J., Wood, J. D., \& Harrington, G. (1998). Fatty acid content and composition of UK beef and lamb muscle in relation to production system and implications for human nutrition. Meat Science, 49, 329-341.

Fisher, A. V., \& de Boer, H. (1994). The EAAP standard method of sheep carcass assessment and dissection procedures. Livestock Production Science, 38, 149-159.

García, J. E. Y. (2002). Catálogo de razas autóctones de Castela e Leão e região Norte de Portugal. I. Espécies ovina, caprina, porcina, cães de gado e galinhas. Serie Monografias y estudios.

Hedrick, H. B., Aberle, E. D., Forrest, J. C., Judge, M. D., \& Merkel, R. A. (1994). Principles of meat science (3rd ed.). Iowa: Kendall and Hunt Publishing Co.

Hogg, B. W., Mercer, G. J. K., Mortimer, B. J., Kirton, A. H., \& Duganzich, D. M. (1992). Carcass and meat quality attributes of commercial goats in New Zealand. Small Ruminant Research, 8, 243-256.

Hopkins, D. L., Fogarty, N. M., \& Menzis, D. J. (1997). Differences in composition, muscularity, muscle:bone ratio and cut dimensions between six lamb genotypes. Meat Science, 45, 439-450.

INE (2003). Available from http://www.idrha.min-agricultura.pt/produtos_tradicionais/estatisticas/pub2003.pdf.

Johnson, D. D., \& McGowan, C. H. (1998). Diet/management effects on carcass attributes and meat quality of young goats. Small Ruminant Research, 28, 93-98.

Johnson, D. D., McGowan, C. H., Nurse, G., \& Anous, M. R. (1995). Breed type and sex effects on carcass traits, composition and tenderness of young goats. Small Ruminant Research, 17, 57-63.

Kadim, T., Mahgoub, O., Al-Ajmi, D. S., Al-Maqbaly, R. S., Al-Saqri, N. M., \& Ritchie, A. (2003). An evaluation of the growth, carcass and meat quality characteristics of Omani goat breeds. Meat Science, 66, 203-210.

Kirton, A. H. (1970). Body composition and meat quality of the New Zealand feral goats (Capra hircus). New Zealand Journal of Agricultural Research, 13, 167-181.

Klont, R. E., Brocks, L., \& Eikelenboom, G. (1998). Muscle fibre type and meat quality. Meat Science, 49, S219-S229.

Labadie, D. K., Laplaud, P. M., Rigaud, M., \& Breton, J. C. (1974). Dosage spécifique des acides gras non-sterifiés du plasma humain. Annales de Biologie Clinique, 32, 59.

Mahgoub, O., \& Lu, C. D. (1998). Growth, body composition and carcass tissue distribution in goats of large and small sizes. Small Ruminant Research, 27, 267-278.

Mahgoub, O., Kadim, I. T., Al-Saqry, N. M., \& Al-Busaidi, R. M. (2005). Potential of Omani Jebel Akhdar goat for meat production under deelot conditions. Small Ruminant Research, 56, 223-230.

Mahgoub, O., Khan, A. J., Al-Maqbaly, R. S., Al-Sabahi, J. N., Annamalai, K., \& Al-Sakry, N. M. (2002). Fatty acid composition of muscle and fat tissues of Omani Jebel Akhdar goats of different sexes and weights. Meat Science, 61, 381-387.

Marichal, A., Castro, N., Capote, J., Zamorano, M. J., \& Argüello, A. (2003). Effects of live weight at slaughter $(6,10$ and $25 \mathrm{~kg})$ on kid carcass and meat quality. Livestock Production Science, 83, 247-256.

Marinova, P., Banskalieva, V., Alexandrov, S., Tzvetkova, V., \& Stanchev, H. (2001). Carcass composition and meat quality of kids fed sunflower oil supplemented diet. Small Ruminant Research, 42, 219-227.

Marmer, W. N., \& Maxwell, R. J. (1981). Dry column method for the quantitative extraction and simultaneous class separation of lipids from muscle tissue. Lipids, 6, 365-371.

Matsuoka, A., Furokawa, N., \& Takahashi, T. (1997). Carcass traits and chemical composition of meat in male and female goats. Journal of Agricultural Science, Tokyo Nogyo Daigaki, 42, 127-135.

McClelland, T. H., Bonaiti, B., \& Taylor, St. C. S. (1976). Breed differences in body composition of equally mature sheep. Animal Production, 23, 281-293.

NP-Norma Portuguesa-122. (1982). Carnes, derivados e produtos cárneos. Determinação do teor de matéria gorda livre. Instituto Português da Qualidade, Lisboa.
Oman, J. S., Waldron, D. F., Griffin, D. B., \& Savell, J. W. (2000). Carcass traits and retail display-life of chops from different goat breed types. Journal of Animal Science, 78, 1262-1266.

Ouali, A., Lepetit, J., Touraille, C., \& Kopp, J. (1994). Cinétique d'attendrissage de la viande de veu. Viandes Prod. Carnés, 15(3), 83-86.

Park, Y. W., \& Washington, A. C. (1993). Fatty acid composition of organ and muscle meat of Alpine and Nubian breeds. Journal of Food Science, 58, 245-253.

Potchoiba, M. J., Lu, C. D., Pinkerton, F., \& Sahlu, T. (1990). Effects of all-milk diet on weight gain, organ development, carcass characteristics and tissue composition, including fatty acids and cholesterol contents, of growing male goats. Small Ruminant Research, 3, 583-592.

Pralomkarn, W., Saithanoo, S., Kochapakdee, S., \& Norton, B. W. (1995). Effect of genotype and plane of nutrition on carcass characteristics of Thai native and Anglo-Nubian $\times$ Thai native male goats. Small Ruminant Research, 16, 21-25.

Riley, R. R., Savell, J. W., Johnson, D. D., Smith, G. C., \& Shelton, M. (1989). Carcass grades, rack composition and tenderness of sheep and goats as influenced by market class and breed. Small Ruminant Research, 2, 273-280.

Santos, V. A. C., Queirós, M. T., Silva, S. R., Fontes, P., Mena, E. G., \& Azevedo, J. M. T. (2002). Composição da carcaça de cabras adultas criadas na região do Barroso. In: Resumos do XII Congresso de Zootecnia, 21-23 Novembro, UTAD, Vila Real, p. 168.

Santos-Silva, J., Mendes, I. A., \& Bessa, R. J. B. (2002). The effect of genotype, feeding system and slaughter weight on the quality of light lambs 1. Growth, carcass composition and meat quality. Livestock Production Science, 76, 17-25.

SAS (1999). SAS user's guide statistics (3rd ed.). Cary, NC: SAS Institute Inc., Version 8.

Sauvant, D., Bas, P., \& Morand-Fehr, P. (1979). Production de Chevreaux lourds: II. Influence du niveau d'ingestion de lait et du sevrage sur les performances et la composition du tissu adipeux. Annales Zootechnie, 28, 73-92.

Schönfeldt, H. C., Naudé, R. T., Bok, W. S., Van Heerden, M., Sowden, L., \& Boshoff, E. (1993). Cooking- and juiciness-related quality characteristics of goat and sheep meat. Meat Science, 34, 381-394.

Sen, A. R., Santra, A., \& Karim, S. A. (2004). Carcass yield, composition and meat quality attributes of sheep and goat under semiarid conditions. Meat Science, 66, 757-763.

SPOC (2005). Available from http://www.ovinosecaprinos.com/ recursos_f.html.

Teixeira, A. J. C., Azevedo, J. M. T., Delfa, R., Morand-Fehr, P., \& Costa, C. (1995). Growth and development of Serrana Kids from Montesinho Natural Park (NE Portugal). Small Ruminant Research, 16, 263-269.

Todaro, M., Corrao, A., Alicara, M. L., Schinelli, R., Giaccone, P., \& Priolo, A. (2004). Effects of litter size and sex on meat quality traits of kid meat. Small Ruminant Research, 54, 191-196.

Todaro, M., Corrao, A., Barone, C. M. A., Schinelli, R., Occidente, M., \& Giaccone, P. (2002). The influence of age at slaughter and litter size on some quality traits of kid meat. Small Ruminant Research, 44, 75-80.

Tshabalala, P. A., Strydom, P. E., Webb, E. C., \& Kock, H. L. (2003). Meat quality of designated South African indigenous goat and sheep breeds. Meat Science, 65, 563-570.

Van Niekerk, W. A., \& Casey, N. H. (1988). The Boer goat. II. Growth, nutrient requirements, carcass and meat quality. Small Ruminant Research, 1, 355-368.

Velasco, S., Cañeque, V., Lauzurica, S., Pérez, C., \& Huidobro, F. (2004). Effect of different feeds on meat quality and fatty acid composition of lambs in relation fattened at pasture. Meat Science, 66, 457-465.

Velasco, S., Cañeque, V., Pérez, C., Lauzurica, S., Díaz, M. T., Huidobro, F., et al. (2001). Fatty acid composition of adipose depots of suckling lambs raised under different production systems. Meat Science, 59, 325-333.

Velasco, S., Lauzurica, S., Cañeque, V., Pérez, C., Huidobro, F., Manzanares, C., et al. (2000). Carcass and meat quality of Talaverana breed suckling lambs in relation to gender and slaughter weight. Animal Science, 70, 253-263. 
Vicenti, A., Ragni, M., Ginnico, F., Vonghia, G., \& Zezza, L. (2001). Omega-3 fatty acid supplementation in bottle feeling for rearing kids. 2. Effects on the chemical composition and fatty acidic profile of meat. Zootecnica e Nutrizione Animale, 27, 147-165.

Warmington, B. G., \& Kirton, A. H. (1990). Genetic and non-genetic influences of growth and carcass traits of goats. Small Ruminant Research, 3, 157-165.

Webb, E. C., Casey, N. H., \& Simela, L. (2005). Goat meat quality. Small Ruminant Research, 60, 153-166.
Wood, J. D., MacFie, H. J., Pomeroy, R. W., \& Twinn, D. J. (1980). Carcass composition in four sheep breeds: the importance of type of breed and stage of maturity. Animal Production, 30, 135-152.

Wood, J. D., Richardson, R. I., Nute, G. R., Fisher, A. V., Campo, M. M., Kasapidou, E., et al. (2003). Effects of acids on meat quality: a review. Meat Science, 66, 21-32.

Zygoyiannis, D., Kufidis, D., Katsaounis, N., \& Phillips, P. (1992). Fatty acid composition of carcass fat of indigenous (Capra prisca) suckled Greek kids and milk of their does. Small Ruminant Research, 8, 83-95. 